\title{
Socio-demographic, Economic and Health Characteristics of Female-Headed Jordanian Households: An Exploratory Descriptive Study
}

\author{
Husein Mohammad Alothman ${ }^{1} \&$ Mohammed Abdel Karim Al-Hourani ${ }^{2}$ \\ ${ }^{1}$ Dean of College of Arts, Humanities, and Social Sciences, University of Sharjah, U.A.E \\ ${ }^{2}$ Sociology Department, University of Sharjah, U.A.E \\ Correspondence: Husein Mohammad Alothman. E-mail: halothman@sharjah.ac.se
}

Received: February 9, 2020

Accepted: April 18, 2020

Online Published: May 31, 2020

doi:10.5539/ass.v16n6p16

URL: https://doi.org/10.5539/ass.v16n6p16

\begin{abstract}
This study aimed to identify the social, economic and health characteristics of Jordanian families headed by females and the differences in these characteristics according to the gender of the head of the household. To achieve this aim, the study utilized data available from the multipurpose family survey conducted by the Department of Statistics in 2003. The survey targeted a national sample using cluster stratified sampling. The number of completed interviews reached 9,711 families. Comparative method was also used to identify the differences between Jordanian families according to the gender of the head of the household.

The study revealed that a number of traditional factors determine whether a family would be headed by a female such as the death of the spouse, especially as a result of the age gap between the husband and wife, economic migration of the husband, and divorce. In addition, the study showed that the social and economic characteristics of Jordanian families were largely homogenous regardless of the gender of the head of the family especially concerning such issues as poverty, family income, and access to health insurance. On the other hand, there were differences in size and the level of education of the head of the family, largely determined by place of residence, governorate of residence and age among those households and among the ones headed by females. The significance of the study stems from the fact that it is a national study that will open new horizons for more in-depth future studies.
\end{abstract}

\section{Introduction}

Jordan is a developing country in the Middle East and is classified as an Arab country with medium human development (United Nations, 2016). Also, Jordan has achieved impressive indicators of education, and health environments (Alothman, 2012a). The objective of this study is to identify the social, economic, and health characteristics of Jordanian families headed by females and the differences in these characteristics according to the gender of the head of the household.

Family has always been of the centre of human societies (Alothman, 2005, 2012b, 2017). Since the 1950s, a number of studies documented family female headship in many developed and developing countries (Lof, 1999; Rogan, 2016). The United Nations' definition of female headship refers to such concepts as the financial responsibilities borne by the female head of the family, the making of crucial decisions, management of the economic affairs of the family, or being the main breadwinner (ESCWA, 2001). The main factors that lead to female headship have been identified as widowhood, divorce (in which cases the female member of the family lives either alone or with her offspring in her home, or with her extended family), the economic migration of the husband, the incarceration of the husband due to criminal acts or political reasons, the unemployment of the husband because of his lack of necessary skills, age or disability, being an unmarried working female in a family where other members are either unemployed or disabled, being abandoned by the husband, or the disappearance of the husband especially during times of war or conflict (ESCWA, 2001).

In 1987, Buvinic et al. (1978) highlighted the increase in the number of female-headed households in developing countries. By the end of the 1980s, the concept of female headship had become relatively more familiar in these societies, although issues existed as to its definition and the extent of its prevalence (Arias \& Palloni, 1996). After this time, the number of this type of households increased in these societies. For example, it reached 13\% 
in the Near East, $16 \%$ in Asia, 22\% in the African Sahara and 24\% in South America (Bongaarts, 2001). It was also evident that the size of these families was smaller compared to those headed by males (Kristiansen, 2003). In the Arab World, females headed approximately $11 \%$ of all households in Algeria, $13 \%$ in Egypt, $15 \%$ in Libya, $13 \%$ in Morocco and 11\% in Sudan (Nosseir, 2003). In 2001, in Lebanon, the West Bank, Gaza and Yemen the percentage of these households were 12.5, 9.5, 8 and 13 respectively (ESCWA, 2001).

The prevalence of this type of household in the industrialized world in general, and the United States in particular, can be attributed to two major factors: the high number of unmarried teen pregnancies especially among the less-privileged communities, and the high rates of divorce and separation (Mooney et al., 2000). This was not the case at the beginning of the twentieth century when widowhood was the major factor.

However, the reasons that lead to female headship differ from one geographical region to another. For example, in rural areas in Africa, the main contributing factor is migration of the males to urban centres in search for work, while the relocation of females to the city causes this phenomenon in rural South America (Arias \& Palloni, 1996). Meanwhile, widowhood is considered the main factor in Lebanon, Yemen, the West Bank and Gaza.

In some developed countries, there is a negative view of female-headed households as they are considered broken families where the head is heavily reliant on social welfare and, therefore, more prone to fall below the poverty line. In addition, these families face a number of obstacles including low income, as the female head of the household cannot work for long hours due to her child-care obligations (Ellwood \& Jencks, 2004).

\section{Research Problem}

Jordanian families have undergone a number of changes in structure and the average age of marriage. One such apparent change is the transformation from an extended to a nuclear family. Also, parental authority is declining and the economic power of women is increasing. As a result, family affairs became a major concern for the relevant agencies in the country, especially those focusing on modifying existing policies and strategies. The number of female-headed households is on the increase in Jordan; however, there is a limited amount of research on the phenomenon. Therefore, this study aims to answer the following questions:

1. What are the demographic and social (marital status, place of residence, level of education, governorate of residence and age), economic (employment, family income and sources of income) and health (health insurance, disability and chronic illness) characteristics of female-headed households compared to male-headed ones?

2. Do some demographic, social, economic and health characteristics differ according to the gender of the head of the household?

\section{Significance of the Study}

The main significance of this study is that it is a national, exploratory and descriptive study of the demographic, social, economic and health characteristics of female-headed households that can be the starting point for future, more comprehensive studies. In addition, there has been very limited research conducted on this issue in Jordan, while the national family strategy has highlighted it as a major issue worthy of further research and study. This strategy, and its executive plan, called specifically for conducting an exploratory preliminary study on this issue.

\section{Literature Review}

Studies on the Jordanian family focus on issues related to family structure, parental authority, poverty, family violence, and marriage and divorce. The subject of female-headed households was not studied despite the availability of secondary data within databases on the characteristics of the Jordanian family. Globally, there is some literature about the characteristics of female-headed households. For instance, Joshi (2004) studied the characteristics of female-headed households and the impact of that headship on the children's schooling in rural Bangladesh. She found that the number of these families increased from $11.6 \%$ of all families in 1974 to $12.9 \%$ in 1982 and then again to $15.2 \%$ in 1996 . The majority of these households were headed by widowed females or those married to economic migrant workers. It was also revealed that families headed by widows were more predisposed to poverty and less probable to own assets. In comparison, families headed by a married female were wealthier than families headed by males because of the difference in family income, the money transfers they received from overseas, and the assets they owned such as gold jewellery and electronic goods. Furthermore, children in these families were less likely to work and more probable to join school and achieve better academically. However, children of male-headed families had the advantage over children of families headed by a widow in these areas.

Another study conducted by the United Nations Economic and Social Commission for Western Asia (ESCWA) 
in Yemen, Lebanon, the West Bank and Gaza in 2001 aimed to inform poverty-countering policies in these countries. In this study, it was found that the number of female-headed households in Lebanon increased from $11.3 \%$ in 1970 to $12.5 \%$ in 1997 . This was also the case in rural areas where their number rose from 6.5 in 1970 to $10.9 \%$ in 1987 . The 1997 data shows that the majority of these families were headed by widows ( $80 \%)$, followed by single (21.5\%), divorced (6\%) and married women (1.5\%). $29 \%$ of these families consisted of only one member, while $59.4 \%$ consisted of 2 to 5 members. In the same year, the percentage of female-headed families in the West Bank and Gaza reached $9.5 \%$ and $8 \%$ of all families, respectively. $28.6 \%$ of these families consisted of one member, whereas $43 \%$ of them consisted of $2-5$ members. The poverty rate among these families was estimated at $30 \%$, compared to $22 \%$ of families headed by a male. The study also revealed that in 1994 a female headed 13\% of all families in Yemen. However, the number of these families varied between urban and rural areas where the percentage of these families was 10 and 14 respectively. $15 \%$ of these families comprised of one member, while $43 \%$ of them had 2-5 members (ESCWA, 2001).

Ellwood and Jencks (2004) studied the 'spread of single-parent families in the United States since 1960.' The study revealed that the decrease in employment opportunities available to men resulted in a fall in the rate of marriage and a rise in the number of single-parent families. In addition, changes in the dominant value systems contributed to the fact that cohabitation and premarital relations became more acceptable.

The types of female-headed families in South America were investigated by Arias \& Palloni (1996) in a study that hypothesised that the increase in the number of these families in developing societies was directly linked to the disintegration of the traditional family and the migration from rural to urban areas due to industrialization and modernization in line with what had occurred in developed countries. However, their findings did not support this hypothesis, at least in the case of the region under study. In spite of the differences among South American countries, there were evident similarities among these types of families especially in relation to such trends as age, levels of female headship of the families, the women's marital status and level of education, the extent of poverty and whether the family resided in a rural or urban area. It was also found that these families were usually extended families and not nuclear, and that there was a large tendency for widowed or divorced women to head the family.

A survey of 39 studies on female-headed families conducted by the Population Council and International Centre for Research on Women revealed that these families are typically poorer than two-parent families in all developing regions under study. It also revealed that there were regional differences in the effects of female headship on child care. For example, in South America, children of these families were more liable to drop out from school, suffer malnutrition, join the workforce and suffer child mortality (Arias \& Palloni, 1996). Other research found that women headed households increase the likely hood to be the poorest of the poor (Buvinic \& Gupta, 1997; Chant, 1997, 2003, 2008; Milazzo \& Van de Walle, 2017; Nwosu \& Ndinda, 2018).

\section{Research Methods}

\subsection{Research Sample}

The sample investigated was designed by the Department of Statistics to meet the objectives of the multi-purpose family survey of 2003 as families that represent the typical Jordanian family in the city, countryside and governorates of the country. Cluster stratified sampling was used in two stages. In the first stage, the preliminary sample units (blocks) were selected using a method of sampling proportional to the size and drawn regularly. In the second stage, a fixed number of families (16) were selected from each sample unit chosen, using the stratified random sampling method from among the preliminary sample units selected. The sample consisted of 10,176 families, where the number of completed interviews reached 9711 families or $95.4 \%$ of the whole sample. In order to answer the research questions, a comparison of the demographic, social, economic and health characteristics was conducted between female-headed families (1360 families) and other families. Also, comparative method was used to analyse the data to identify the differences between Jordanian families according to the gender of the head of the household.

\section{Findings}

\subsection{Percentage of Female-Headed Families in Jordan}

The study revealed that $14 \%$ of families in Jordan are headed by a female member (Table 1). This is higher compared to the results of the life conditions survey of 1996 (11\%) (Department of Statistics, 1996), the population and family health survey of $2002(11.5 \%)$, and the family expenses and income survey of 2002-2003 $(10.5 \%)$ (Department of Statistics, 2003). This disparity can be attributed to the differences in measurement methods of this variable employed by each survey, where the gender of the head of the family was determined by 
subjective reporting. Although this is a commonly used method, it leads to an underestimation of the number of female-headed families and limits the extent of this phenomenon to traditional cases such as widowhood, divorce or the economic migration of the husband. Consequently, identifying the gender of the head of the household is determined by the extent of self-awareness enjoyed by the surveyed individuals, which may not accurately reflect the various facets of female headship. This calls for strict adherence to the UN's definition of female headship on the part of researchers and in national surveys. As a result, the percentage of female-headed households in Jordan may highly exceed those declared by national surveys.

Table 1. Percentage of families according to the gender of the head of the household

\begin{tabular}{ccc}
\hline Gender of the Head of the Household & Number & $\%$ \\
\hline Male & 8351 & 86 \\
Female & 1360 & 14 \\
Total & 9711 & 100 \\
\hline
\end{tabular}

\subsection{Demographic and Social Characteristics}

\section{- $\quad$ Family size}

As a social institution, family is of particular importance both to the individual and society. The size of the family affects its welfare and adds to the economic burdens placed on its head. Jordanian families are comparatively large with a national average of 5.73 members per family (Table 2). This study found that family size varies according to the gender of the head of the household. To illustrate, a female-headed family averaged 4.32 members compared to 5.98 in male-headed families. This is consistent with the findings of the family expenses and income survey of 2002-2003 (Department of Statistics, 2004). This disparity may be attributed to the demise or economic migration of the husband.

Table 2. Mean and standard deviation of the number of family members by gender of the head of the household

\begin{tabular}{cccc}
\hline Gender of the Head of the Household & Male & Female & Nationwide \\
\hline Mean & 5.98 & 4.23 & 5.73 \\
Standard Deviation & 2.56 & 2.65 & 2.66 \\
\hline
\end{tabular}

On the other hand, it was found that $15.2 \%$ of female-headed families consisted of only one member compared to only $1 \%$ of those headed by a male (Table 3 ). This type of family comprises only $2.8 \%$ of families nationwide. It can also be observed that of families comprised of 2-4 members, $44.9 \%$ were female headed while $29.3 \%$ were headed by a male. Families of 5-7 members were mostly headed by males (45\%) as compared to those headed by females $(29.1 \%)$. This trend is more evident in families comprised of more than 7 members. As for families comprised of 8 members, $11 \%$ of those were headed by females, whereas $25 \%$ were headed by men.

Table 3. Size of household according to the gender of the head of the family

\begin{tabular}{cccc}
\hline \multirow{2}{*}{ Family Size } & \multicolumn{2}{c}{ Gender of the Head of the Family } & \multicolumn{2}{c}{ Nationwide } \\
\cline { 2 - 4 } & Male & Female & $\%$ \\
\cline { 2 - 3 } 1 & 0.8 & $\%$ & 2.8 \\
$2-4$ & 29.3 & 45.2 & 31.4 \\
$5-7$ & 45 & 29.1 & 42.7 \\
$8-10$ & 20 & 8.8 & 18.4 \\
More than 10 & 4.9 & 2 & 4.7 \\
& $100 \%$ & $100 \%$ & $100 \%$ \\
\end{tabular}

\section{- Marital status}

Being married is the most common marital status among Jordanian men and women with a number of cases of being widowed or divorced. However, there is an increase in the number of widows after the age of forty. This has led to making widowhood the main factor contributing to the number of cases of female family headship. 
This is followed by the economic migration of the husbands to seek employment mainly in the Arabian Gulf countries and then by divorce. The findings of his study, for example, reveal that almost two thirds, or $67.3 \%$, of female heads of households in Jordan are widows (table 4). A quarter of those cases are married (24.6\%) and a small number of them are divorced (3.8\%) or have never been married (3.5\%). This demonstrates that the main reason for female headship is widowhood, which can be attributed to the age gap between the couple, as Jordanian men tend to marry younger women. It is also common in Jordanian society for a widowed wife to remain unmarried, whether by choice or because of lack of opportunity, after the demise of her husband to care for the children, which is a stringent part of Jordanian culture.

Table 4 . The percentage of family heads by gender and marital status

\begin{tabular}{|c|c|c|c|}
\hline \multirow{2}{*}{ Marital Status } & \multicolumn{2}{|c|}{ Gender } & \multirow{2}{*}{ Nationwide } \\
\hline & Male & Female & \\
\hline Never married & $1.5 \%$ & $3.5 \%$ & $1.8 \%$ \\
\hline Married & $97.2 \%$ & $24.6 \%$ & $87 \%$ \\
\hline Divorced & $0.2 \%$ & $3.9 \%$ & $0.7 \%$ \\
\hline Widowed & $1.2 \%$ & $68 \%$ & $10.4 \%$ \\
\hline Separated & $0.0 \%$ & $0.0 \%$ & $0.1 \%$ \\
\hline Total \% & $100 \%$ & $100 \%$ & $100 \%$ \\
\hline Total Number & 8351 & 1360 & 9711 \\
\hline
\end{tabular}

The causes for female family headship in Jordan are similar to those in Yemen, Lebanon, Palestine, Bangladesh and industrialized countries at the turn of the twentieth century. However, they are different from the causes of this phenomenon in developed countries, where the shift in social views of marriage and sexual relations, the emergence of alternative types of marriages and the increase in the rate of divorce and separation have been the main contributing factors.

Furthermore, there was a noticeable difference in the percentage of female-headed households among these groups according to the place of residence (Table 5). To illustrate, the percentage of married female heads of family in urban areas was higher than in the countryside, at $25.6 \%$ and $19.6 \%$ respectively. This can be attributed to the fact that city residents have more opportunities to migrate overseas in search of employment. In contrast, more widowed women head their families in rural areas (73.8\%) than in urban centres $(66.1 \%)$. This variance can be explained by the fact that the age gap between husband and wife is higher in the rural areas.

Table 5. Gender, marital status and place of residence of family heads

\begin{tabular}{|c|c|c|c|c|}
\hline \multirow{2}{*}{ Place of Residence } & \multirow{2}{*}{ Marital Status } & \multicolumn{2}{|c|}{ Gender } & \multirow{2}{*}{ Nationwide $\%$} \\
\hline & & Male & Female & \\
\hline \multirow{6}{*}{ Urban Areas } & Never married & $1 \%$ & $3.7 \%$ & $2.4 \%$ \\
\hline & Married & $96 \%$ & $25.6 \%$ & $60.8 \%$ \\
\hline & Divorced & $2.0 \%$ & $3.8 \%$ & $3 \%$ \\
\hline & Widowed & $1.3 \%$ & $66.1 \%$ & $33.7 \%$ \\
\hline & Separated & $0.0 \%$ & $0.0 \%$ & $0.0 \%$ \\
\hline & $\%$ & 100 & 100 & 100 \\
\hline \multirow{6}{*}{ Rural Areas } & Never married & $1 \%$ & $2.7 \%$ & $1.8 \%$ \\
\hline & Married & $90 \%$ & $19.6 \%$ & $54.8 \%$ \\
\hline & Divorced & $1.0 \%$ & $3.6 \%$ & $2.3 \%$ \\
\hline & Widowed & $8.0 \%$ & $73.8 \%$ & $40.9 \%$ \\
\hline & Separated & $0.0 \%$ & 0.0 & $0.0 \%$ \\
\hline & $\%$ & $100 \%$ & $100 \%$ & $100 \%$ \\
\hline
\end{tabular}

\section{- $\quad$ Area of residence}

It was found that the vast majority of female-headed households were in urban centres (83.5\%) as compared to rural areas $(16.5 \%)$. This can be explained by the fact that most Jordanian families reside in cities. 
Table 6. Distribution of female-headed households according to area of residence

\begin{tabular}{ccc}
\hline Area of Residence & Number & $\%$ \\
\hline Urban Areas & 1135 & 83.5 \\
Rural Areas & 225 & 16.5 \\
Total & 1360 & 100 \\
\hline
\end{tabular}

These results raise the question whether the percentage of female-headed households differ according to the area of residence of the family. This study revealed that $14.7 \%$ of those families resided in urban centres compared to only $11.2 \%$ in the countryside, which is consistent with the findings of a number of previous studies (Table 7). This disparity can be attributed to the larger opportunities for work overseas urban residents have as compared to those residing in the countryside and to the bigger age gap between spouses in rural areas.

Table 7. Distribution of Jordanian families according to the gender of the family head and area of residence

\begin{tabular}{|c|c|c|c|}
\hline \multirow{2}{*}{ Area of Residence } & \multicolumn{2}{|c|}{ Gender } & \multirow{2}{*}{ Nationwide } \\
\hline & Male & Female & \\
\hline Urban Areas & $85.3 \%$ & $14.7 \%$ & $100 \%$ \\
\hline Rural Areas & $88.8 \%$ & $11.2 \%$ & $100 \%$ \\
\hline \multirow{2}{*}{ Total } & $86 \%$ & $14 \%$ & $100 \%$ \\
\hline & 8351 & 1360 & 9711 \\
\hline
\end{tabular}

\section{- $\quad$ Level of education}

Education is a basic human need as it equips individuals with the skills they need, increases their productivity and enables them to acquire positive attitudes and mores. It is a valuable human asset and an essential part of human development (Alothman, 2012a). From a human development perspective, the education of women is an essential requirement for their empowerment.

This study found a correlation between the level of education and the gender of the head of a household (Table 8). It was revealed that $68.9 \%$ of the females heading a household in Jordan were totally illiterate or could only read and write compared to $36.4 \%$ of male heads. It was also observed that female family heads are less educated than their male counterparts. For instance, two and a half times as many male family heads (18.7\%) as females (7.7\%) had finished their basic education, while twice as many males had completed their secondary education. Similarly, the number of male family heads who had post-secondary school education was double that of female family heads $(12 \%)$.

Table 8 . Level of education by gender of family heads

\begin{tabular}{|c|c|c|c|}
\hline \multirow{2}{*}{ Level of Education } & \multicolumn{2}{|c|}{ Gender } & \multirow{2}{*}{ Nationwide } \\
\hline & Male & Female & \\
\hline Illiterate/Can Read and Write & $36.4 \%$ & $68.9 \%$ & $41 \%$ \\
\hline Basic Education & $18.7 \%$ & $7.7 \%$ & $17.2 \%$ \\
\hline Secondary Education & $20.6 \%$ & $11.4 \%$ & $19.3 \%$ \\
\hline Post-Secondary Education & $24.2 \%$ & $12 \%$ & $22.5 \%$ \\
\hline Total \% & $100 \%$ & $100 \%$ & $100 \%$ \\
\hline Total number & 8351 & 1360 & 9711 \\
\hline
\end{tabular}

\section{- $\quad$ Governorate of residence and Gender}

It is also worth investigating whether the percentage of female-headed households compared to the general population varied according to the governorate of residence. It was shown that Amman had the highest rate of incidence of this type of family (16.4\%) compared to Aqaba which recorded the lowest rate with $8.2 \%$. In fact, eight governorates recorded a rate lower than the national average of $14 \%$ : Ajloun 11\%, Balqa $11.1 \%$, Jarash $11.3 \%$, Almafraq 11.6\%, Zarqa 11.9\%, Madba 12.3\%, Irbid 13.7\% and Aqaba 8.2\%. In contrast, Ma'an, Alkarak and Amman recorded higher rates than the national average with $14.9 \%, 14.7 \%$ and $16.4 \%$ respectively (Table 9). This disparity in the percentage of female-headed households among different governorates can be attributed to 
the variance in the number of opportunities to work overseas residents of these areas have and the difference in the age gap between spouses in them.

Table 9. Distribution of families according to the gender of the family head and governorate of residence

\begin{tabular}{|c|c|c|c|}
\hline \multirow{2}{*}{ Governorate } & \multicolumn{2}{|c|}{ Gender } & \multirow{2}{*}{$\%$} \\
\hline & Male & Female & \\
\hline Amman & $83.6 \%$ & $16.4 \%$ & 100 \\
\hline Balqa & $88.9 \%$ & $11.1 \%$ & 100 \\
\hline Zarqa & $88.1 \%$ & $11.9 \%$ & 100 \\
\hline Madba & $87.7 \%$ & $12.3 \%$ & 100 \\
\hline Almafraq & $88.4 \%$ & $11.6 \%$ & 100 \\
\hline Jarash & $88.7 \%$ & $11.3 \%$ & 100 \\
\hline Ajloun & $89 \%$ & $11 \%$ & 100 \\
\hline Alkarak & $85.3 \%$ & $14.7 \%$ & 100 \\
\hline Altufailah & $88.1 \%$ & $11.9 \%$ & 100 \\
\hline Ma'an & $85.1 \%$ & $14.9 \%$ & 100 \\
\hline Aqaba & $91.8 \%$ & $8.2 \%$ & 100 \\
\hline Nationwide & $86 \%$ & $14 \%$ & 100 \\
\hline
\end{tabular}

\section{- Age}

It was revealed that the vast majority $(87.7 \%)$ of female family heads were over 40 years of age. In stark contrast, no incidences of female headship were recorded for the age group 15-19. Furthermore, it was observed that there was a positive correlation between the age of the matriarch and the percentage of female-headed households. For example, $1.2 \%$ of these households were headed by 20 to 24 -year-old females compared to $5.5 \%$ headed by 35 to 39 -year-olds (Table 10). This can be attributed to the age gap between spouses in Jordanian society, where husbands are older and usually pass away before their wives.

Table 10. Distribution of female-headed households by age

\begin{tabular}{ccc}
\hline Age Group & Number & Percentage \\
\hline $20-24$ & 16 & 1.2 \\
$25-29$ & 17 & 1.2 \\
$30-34$ & 50 & 4.4 \\
$35-39$ & 75 & 5.5 \\
$40-44$ & 110 & 8.1 \\
$45-49$ & 157 & 11.6 \\
$50-54$ & 180 & 13.2 \\
$55-59$ & 195 & 14.3 \\
$60-64$ & 158 & 11.6 \\
$65-69$ & 160 & 11.1 \\
$70-74$ & 119 & 8.7 \\
75 and older & 123 & 9.0 \\
Total & 1360 & 100.0 \\
\hline
\end{tabular}

The data presented in Table 11 below show that the percentage of female-headed households increases in proportion with the age of the family head. For example, the age group 70-74 recorded the highest rate with 30\%, followed by the age group 75 and older (28.6\%) and then the 65-69 group (24.4\%), while the age group 25-29 recorded the lowest rate with $2.7 \%$. 
Table 11. Distribution of families according to the gender and age of the head of the household

\begin{tabular}{cccc}
\hline \multirow{2}{*}{ Age Group } & \multicolumn{2}{c}{ Gender } & Percentage \\
\cline { 2 - 4 } & $0.0 \%$ & $0.0 \%$ & $0.0 \%$ \\
$20-19$ & $87.8 \%$ & $12.2 \%$ & 100 \\
$25-29$ & $97.3 \%$ & $2.7 \%$ & 100 \\
$30-34$ & $95.1 \%$ & $4.9 \%$ & 100 \\
$35-39$ & $94.8 \%$ & $5.2 \%$ & 100 \\
$40-44$ & $90.9 \%$ & $9.1 \%$ & 100 \\
$45-49$ & $85.3 \%$ & $14.7 \%$ & 100 \\
$50-54$ & $87.35 \%$ & $21.7 \%$ & 100 \\
$55-59$ & $78.9 \%$ & $21.1 \%$ & 100 \\
$60-64$ & $80.2 \%$ & $19.8 \%$ & 100 \\
$65-69$ & $75.6 \%$ & $24.4 \%$ & 100 \\
$70-74$ & 69.3 & $30.7 \%$ & 100 \\
75 and older & $71.4 \%$ & $28.6 \%$ & 100 \\
& $86 \%$ & $14 \%$ & $100 \%$ \\
Nationwide & 8351 & 1360 & 9711 \\
\hline
\end{tabular}

\section{- $\quad$ Economic Characteristics}

This part deals with a number of economic characteristics of female heads of households such as their employment and family income, and its sources. Unfortunately, data available from the Department of Statistics were insufficient to investigate these areas in depth. This important issue needs to be addressed in future surveys conducted by the department.

\section{- Employment}

Increasing employment opportunities for both men and women is a major aim of human development. In spite of the high rates of education among Jordanian women, their employment opportunities and economic activity have not seen a similar growth.

It can be seen from the data presented below that the vast majority of female household heads $(89.4 \%)$ are economically inactive. This is three times the number of economically inactive patriarchs $(25.5 \%)$. The number of working male family heads $(70.6 \%)$ was also revealed to be seven times that of their female counterparts. In addition, only a small percentage of female family heads were unemployed (1.5\%) compared to their male counterparts $(3.9 \%)$ (Table 12$)$.

Table 12. Distribution of Jordanian families according to the gender and employment of their heads

\begin{tabular}{cccc}
\hline \multirow{2}{*}{ Employment } & \multicolumn{2}{c}{ Gender } & \multirow{2}{*}{ Nationwide } \\
\cline { 2 - 3 } & Male & Female & $62 \%$ \\
Employed & $70.6 \%$ & $9.1 \%$ & $3.5 \%$ \\
Unemployed & $3.9 \%$ & $1.5 \%$ & $34.5 \%$ \\
Economically Inactive & $25.5 \%$ & $100 \%$ & $100 \%$ \\
Total & $100 \%$ & & $39 \%$ \\
\hline
\end{tabular}

It was also shown that $57.1 \%$ of families nationwide have health insurance. $57.8 \%$ of male-headed households had health insurance compared to $52.8 \%$ of those headed by a female. This small difference (5\%) between the two groups indicates that the gender of the head of the household has little effect on whether they have health insurance. This may be because it is commonly transferred to the female head of the family after the demise of her husband. 
Table 13. Distribution of Jordanian families according to the gender of the household and obtaining health insurance

\begin{tabular}{|c|c|c|c|}
\hline \multirow{2}{*}{ Health Insurance } & \multicolumn{2}{|c|}{ Gender } & \multirow{2}{*}{ Nationwide } \\
\hline & Male & Female & \\
\hline Have & $57.8 \%$ & $52.8 \%$ & $57.1 \%$ \\
\hline Do not have & $42.2 \%$ & $47.2 \%$ & $42.9 \%$ \\
\hline Total & $100 \%$ & $100 \%$ & $100 \%$ \\
\hline
\end{tabular}

However, there is a link between area of residence and the availability of health insurance to Jordanian families (Table 14). It can be noticed that more than two-thirds (67.7) of families residing in rural areas have health insurance compared to nearly half $(51.4 \%)$ of those living in cities. The situation is very similar when considering the gender of the head of the household as $73.8 \%$ of female-headed households and $79.3 \%$ of male-headed families in rural areas have health insurance compared to $51.9 \%$ of female-headed households and 48.6 male-headed households in urban areas. This can be explained by the fact the majority of residents in rural areas are employed by the armed forces which provides them with health insurance.

Table 14. Availability of health insurance to families according to the gender of the family head and area of residence

\begin{tabular}{ccccc}
\hline \multirow{2}{*}{ Area of Residence } & Health Insurance & \multicolumn{2}{c}{ Gender } & \multirow{2}{*}{$\%$} \\
\cline { 3 - 4 } & & Male & Female & $51.4 \%$ \\
\multirow{3}{*}{ Urban Areas } & Insured & $51.9 \%$ & $48.6 \%$ & $48.6 \%$ \\
& Uninsured & $48.1 \%$ & $51.4 \%$ & 100 \\
& $\%$ & 100 & 100 & $78.7 \%$ \\
Rural Areas & Insured & $79.3 \%$ & $73.8 \%$ & $21.3 \%$ \\
& Uninsured & $20.7 \%$ & $26.2 \%$ & 100 \\
\hline
\end{tabular}

- Disability and chronic illness

Disabilities, whether physical, psychological or social, can limit the activities of the individual. This part of the study focuses on different types of disabilities and chronic illnesses, like diabetes and cancer, which affect the lives of many family heads.

In the sample of study, the rate of disability among men, women and their children was very low. For example, only $1.5 \%$ of male family heads were disabled compared to only $0.6 \%$ of their female counterparts. In patriarchal families, the proportion of children with disabilities was $1.4 \%$, while it only reached $1.0 \%$ in female-headed households. In contrast, almost a quarter $(23.7 \%)$ of male and nearly half $(51.1 \%)$ of female family heads suffered from a chronic disease. This indicates a significant difference between the number of disabled and chronically ill family heads according to the gender of the head of the household.

Table 15. The relative distribution of heads of families and their children by the gender of the head of the household, disability and chronic diseases

\begin{tabular}{ccccccc}
\hline Disabilities and Chronic Illness & & Disability & Chronic Illness & Both & None & $\%$ \\
\hline \multirow{2}{*}{ Gender of Head of the Family } & Male & 1.5 & 23.7 & 1.0 & 73.8 & 100 \\
& Female & 0.6 & 51.1 & 1.3 & 47.1 & 100 \\
& Male & 1.4 & 2.3 & 0.1 & 96.3 & 100 \\
\multirow{2}{*}{ Children (according to the gender of the head of the family) } & Female & 1.0 & 1.3 & 0.1 & 97.6 & 100 \\
\hline
\end{tabular}

\section{Conclusion}

The results of this comparative study indicate that there is a serious need to review the definition of female 
headship to reflect its varied dimensions and its measurement in national surveys and studies. It was evident, for example, that the assessment of the spread of this type of family varied in different surveys in Jordan from $10.5 \%$ to $14 \%$.

It was also clear that in Jordan this phenomenon is mainly caused by widowhood, as a result of the age gap between husband and wife, and secondly by the economic migration of the male spouse. In addition, the underlying causes of these incidents in Jordan are similar to those in some other Arab countries like Yemen, Palestine, and Lebanon and some developed countries at the start of the twentieth century. However, they differ from those currently associated with the female headship in developed societies like the changes in the social views of marriage and sexual relations, the spread of cohabitation and other forms of partnerships, the application of more liberal divorce laws and the belief in personal values that prize individual freedom.

Furthermore, it was found that a quarter of female family heads are widowed, a quarter married, and the rest are either divorced or have never married. Additionally, the percentage of married female family heads is higher in urban centres than rural areas. In contrast, more widowed females head their families in the countryside than in the city. Another related factor is the governorate of residence as the number of widowed female family heads is the highest in Alkark and the lowest is in Madba. Zarq and Amman recorded the highest number of incidences where the female heads of the household were married, while Balqa and Madba the lowest. Age is another contributing factor and it was demonstrated in this study that fewer young women head their families.

In Jordan, female-headed households have on average a lower number of family members and consist of just one member more often than those headed by men. Four-fifths of those families reside in urban areas. This study also found that there is a significant difference in the level of education of the head of the household according to gender. For example, the level of illiteracy is higher among female family heads than male ones. In fact, the higher the level of education, the higher the representation of male heads of family and vice versa. Another important variable is the governorate of residence of the family. It was found that the capital city, Irbid and Zarqa have higher numbers of female-headed households with Amman, the capital, recording the highest number of incidents and Aqaba the lowest. In addition, age seems to be a contributing factor with four-fifths of female family heads being over forty years of age.

As for the economic characteristics of these families, it was revealed that more than four-fifths of all female family heads are economically inactive and only one-fifth of them are employed. In addition, there is no significant difference in family income based on the gender of the head of the household. This contradicts the results of a number of previous studies.

In exploring the health characteristics of these families, it was found that there is no significant difference in the availability of health insurance based on the gender of the head of the household and that almost half of both male-headed and female-headed families are covered. However, the area of residence has a clear effect on the availability of health insurance to the families under study, based on the gender of the head of the family. Families in rural areas have greater access to health insurance than those living in urban centres regardless of the gender of the head of the family. In addition, it was evident that there is a significant difference in the rate of incidence of disability and chronic illness among Jordanian families, which is linked to the gender of the head of the family: nearly half of female family heads suffered some sort of disability or chronic illness compared to only a quarter of their male counterparts.

It can then be concluded that Jordanian families experience similar social and economic conditions regardless of the gender of the head of the household especially in regard to levels of poverty, family income and access to health insurance. On the other hand, there are significant differences in such areas as family size, the education level of the head of the family, area of residence, governorate of residence, age of the family head and the prevalence of chronic illnesses and disabilities. It can also be concluded that the spread of female-headed households does not indicate a disintegration of the traditional family relations. However, we should be wary of changes that may affect the traditional constitution of marriage and family structure. This can be countered by conducting further studies on female-headed households in the country. We also recommend that in-depth studies should investigate the effect of female headship on child raising and child delinquency.

\section{References}

Alothman, H. (2005a). Jordanian Beilefs in Al-Karak Governorate about the Causes and Determinants of Poverty: Field Stydy. Journal of Development and Economic Polocies, 7(2), 7-36.

Al-Othman, H. (2012). Modernization and dependency in the Arab world's human development: Jordan as case study. European journal of social sciences, 29(2), 260-269. 
Al-Othman, H. M. (2012b). Marital happiness of married couples in the UAE society: A sample from Sharjah. Asian Social Science, 8(4), 217.

Alothman, H. (2017). Beliefs about Causes of Wealth and Poverty: A Field Study in the United Arab Emirates. Arab Journal of Sociology, 20, 335-362.

Arias, E., \& Palloni, A. (1996). Prevalence and patterns of female-headed households in Latin America (pp. 96-14). Center for Demography and Ecology, University of Wisconsin--Madison.

Bongaarts, J. (2001). Household size and composition in the developing world in the 1990s. Population studies, 55(3), 263-279.

Buvinic, M., Youssef, N. H., \& Von Elm, B. (1978). Women-headed households: The ignored factor in development planning (p. 5). Washington, DC: International Center for Research on Women.

Chant, S. (1997). Women-headed households: Diversity and dynamics in the developing world. Springer.

Chant, S. (2003). Female Household Headship and the Feminisation of Poverty: Facts. Fictions and Forward Strategies (London: London School of Economics, Gender Institute, New Working Paper Series, Issue 9).

Chant, S. (2008). Dangerous equations? How female-headed households became the poorest of the poor: Causes, consequences and cautions.

Department of Statistics. (2003). Expenditure and Income household survey 2002-2003. Amman: Jordan.

Department of Statistics. (1996). Life conditions Survey. Amman: Jordan.

Ellwood, D. T., \& Jencks, C. (2004). The spread of single-parent families in the United States since 1960.

ESCWA. (2001). Female-headed households in selected conflict-stricken ESCWA areas: an exploratory survey for formulating poverty alleviation policies. Economic and Social Commission for Western Asia. United Nations.

Joshi, S. (2004). Female household-headship in rural Bangladesh: incidence, determinants and impact on children's schooling. Yale University Economic Growth Center Discussion Paper, (894).

Kristiansen, N. (2003). Iranian Female Headed Housholds. Retrieved from http://kjonnsforskning.no/en/2003/08/iranian-female-headed-households

Lof, G. (1999). Female-Headed Households and Science: Objectification or Humanization, June 20-26, 1999. Women's World 99. Tromso: Women's World 99, 7th International Interdisciplinary Congress on Women.

Milazzo, A., \& Van de Walle, D. (2015). Women left behind? Poverty and headship in Africa. The World Bank.

Mooney, L., Knox, D., \& Schacht, C. (2000). Understanding Social Problems. Belmont: Wadsworth.

Nosseir, N. (2003). Family in the New Millennium : Major Trends Affecting Families in North Africa. The UN Department of Economic and Social Affairs. Retrieved from https://www.un.org/development/desa/family/publications/major-trends-affecting-families.html

Nwosu, C., \& Ndinda, C. (2018). Female household headship and poverty in South Africa: An employment-based analysis.

Rogan, M. (2016). Qualitative perceptions of the meaning of "headship" and female-headed households in post-apartheid South Africa. Social Dynamics, 42(1), 175-195.

United Nations. (2016). Demographic Yearbook. New York: United Nations. https://unstats.un.org/unsd/demographic-social/products/dyb/dyb_2016/

\section{Copyrights}

Copyright for this article is retained by the author(s), with first publication rights granted to the journal.

This is an open-access article distributed under the terms and conditions of the Creative Commons Attribution license (http://creativecommons.org/licenses/by/4.0/). 